\title{
As musas de Jorge de Lima em Invenção de Orfeu*
}

\author{
Luciano Marcos Dias Cavalcanti**
}

\section{Resumo}

Este texto pretende examinar a presença da figura da Musa em Invenção de Orfeu de Jorge de Lima. Para isso, faremos uma pequena introdução sobre a origem e significado da Musa, para, logo após, analisar como Jorge de Lima se utilizou dessa tradição mítica da criação poética na elaboração de seu poema.

\section{Palavras-chave}

Mito. Musa. Memória. Invenção de Orfeu. Jorge de Lima.

Uma importante característica presente em Invenção de Orfeu é a estreita relação da poesia com o mito. Poesia e mito estão entrelaçados em todo o poema no sentido de que o poeta recria a história total: do tempo anterior à Queda até o tempo futuro, em que ele espera o juízo final, momento em que o homem será salvo definitivamente de todo seu sofrimento. Em uma investida mitopoética, através do verbo, o poeta busca recompor o mundo. Desarticulando a linguagem que procura imitar o real, o poeta volta-se para o irracional e para o mágico na procura da linguagem primordial do homem, em que a metáfora, o mistério e o sagrado são privilegiados.

O que vemos no "épico" limiano é a estreita relação do texto literário associado à dimensão mítica, no sentido de que, numa de suas fortes marcas, o poema busca uma espécie de "memória profunda" da cultura, trazendo para o presente um passado mítico perfeito. De acordo com essa perspectiva, é pela poesia que o poeta deseja vivenciar os momentos de um mundo inicial. Esse aspecto é notado não só por seu desejo de reencontrar o passado, mas também pelo próprio ritmo do poema entregue à inspiração divina, livre de quaisquer amarras e por suas imagens. $O$ poeta busca atingir as camadas mais profundas do ser através da correspondência entre o mundo edênico do passado mítico e seu poema. Para isso, o poeta buscará o auxílio das musas e da graça divina para construir seu poema.

\footnotetext{
* Este texto é parte integrante da pesquisa de Pós-doutorado, em andamento, denominada "Mito e poesia na lírica final de Jorge de Lima", sob supervisão do Professor Doutor Antônio Donizeti Pires, junto ao departamento de Literatura/UNESP-Araraquara financiada pela FAPESP.

** Departamento de Literatura, Faculdade de Ciências e Letras, Universidade Estadual Paulista Júlio de Mesquita Filho, UNESP.
} 
Na Grécia antiga, a memória foi encarnada pela deusa Mnemosine, mãe das nove musas. O poeta, inspirado pelas Musas, tinha a função de glorificar os fatos passados e futuros, situação que o assemelha ao profeta. É a testemunha inspirada dos "tempos antigos" e da "idade das origens". Segundo Vernant, em Mito e pensamento entre os gregos, a memória (Mnemosyne), caracterizava-se, no pensamento mítico e arcaico grego, por ter o conhecimento do Tempo: o passado, o presente e o futuro. Mnemosyne tinha, igualmente, o conhecimento do Espaço: do mundo do visível e invisível, do espaço dos vivos e dos mortos. Mnemosyne não era, como a memória, conhecimento de um tempo passado, mas, ao contrário, memória de um tempo que continua no presente e no futuro, pois é memória de um tempo arcaico (arché), primordial, original da formação e organização do mundo e do espaço. A memória mítica e arcaica, portanto, tem, segundo Vernant, a onisciência: ela vê tudo em todos os momentos. Ela está além do começo e do fim. Ela tem sabedoria suprema ao conhecer o passado, o presente e o ausente, o todo do tempo e do espaço e, como que por adição, aquilo que excede esse todo. Possuído pelas musas o poeta é o intérprete de Mnemosyne. (ver VERNANT, 1990, p. 105-131). Portanto, é pela memória que o poeta consegue superar os limites determinados pela espaciotemporalidade ordinária e material e ir além do mundo sensível.

A memória também está associada aos atos ligados à criação: inventar, medir, refletir, cuidar. É através da memória, que a unidade é revelada. Nela, presente passado e futuro se fundem. No momento em que o poeta é possuído pelas Musas, ele absorve o conhecimento de Mnemosine, dessa maneira, ele obtém todo conhecimento expresso pelas genealogias, atingindo o ser em toda a sua profundidade. É a descoberta da origem, do movimento primordial: a gênese dos deuses, o nascimento da humanidade, o surgimento do cosmos. Portanto, é por meio da memória que o poeta tem acesso ao indecifrável e consegue enxergar o invisível. Como aponta Eliade, "graças a memória primordial que ele é capaz de recuperar, o poeta inspirado pelas Musas tem acesso às realidades originais. Essas realidades manifestam-se nos Tempos míticos do princípio e constituem o fundamente deste Mundo" (ELIADE, 1998, p. 108). $O$ canto das Musas revela como o mundo e seus habitantes surgiram. Esse poder ontofânico pode ser evidenciado hoje na experiência poética, isto ocorre quando a poesia consegue fundar uma realidade própria a ela, quando funda seu próprio mundo.

Mnemosine, ao revelar ao poeta os segredos do passado, o introduz nos mistérios do Além. A memória aparece então como um dom para iniciados, e a anamnesis, a reminiscência, como uma técnica ascética e mística. Também a memória participa das doutrinas órficas e pitagóricas, ela é o antídoto do esquecimento. No inferno órfico, o morto deve evitar a fonte do esquecimento, não deve beber no Lates, mas, ao contrário, nutrir-se da fonte da memória, que é uma fonte de imortalidade. Nos pitagóricos, estas crenças combinam-se com uma doutrina da reencarnação das almas, e a via da perfeição é a que conduz à lembrança de todas as vidas anteriores. (ver LE GOFF, 2003, p. 434). Na perspectiva cristã, a memória se revela como um sistema essencial e um exercício fundamental, pois está ligada a lembrança do Paraíso e do Inferno. 
No âmbito literário "moderno", é interessante a perspectiva desenvolvida por Vico em seu De antiqüíssimo Italorum sapientia (1710), no qual percebemos a ligação entre memória e imaginação, memória e poesia.

entre os Latinos chama-se "memória" a faculdade que guarda as percepções recolhidas pelos sentidos, e "reminiscência" a que as dá à luz. Mas memória significa também a faculdade pela qual nós conformamos as imagens, e que as dá, e que os Gregos chamaram "fantasia", e nós comumente dizemos "imaginar" dizem os Latinos memorare. Será, por acaso, porque não podemos fingir em nós senão o que pelos sentidos percebemos? De certo, nenhum pintor pintou jamais qualquer gênero de planta ou de ser animado que não o retirasse da natureza: porque hipogrifos e centauros são verdades da natureza ficticiamente combinadas. (apud BOSI, 1977, p. 200 [Vico - De Antiqüíssimo, cit. VII, 2]).

Desse modo, Alfredo Bosi, ao analisar a passagem de Vico, afirma que a criação poética é fruto da memória, no sentido em que ela "aparece como faculdade de base" (BOSI, 1977, p. 204). E o meio pelo qual se "modela" a imagem é a fantasia. Desta se produz tanto os mitos quanto a prática poética em si, o texto. Aliado a isso, podemos pensar que a memória no texto literário tem o papel de reelaborar o que foi vivido (ou imaginado) pelo poeta de modo que ela possa se realizar no poema. Sem essa reelaboração a memória simplesmente representaria o passado comum a qualquer pessoa.

Em entrevista cedida a Homero de Senna, Jorge de Lima revela que a expressão da memória em sua poesia se dá pela influência de Marcel Proust. O Poeta teria sido um dos primeiros leitores de Proust no Brasil, o que provavelmente o marcara, dada sua relação com a memória afetiva, como também demonstra a desarticulação do tempo linear em sua poesia.

\begin{abstract}
Mas não só pelo relativismo introduzido em nossa literatura se fez sentir no Brasil a influência de Proust. Esta se nota também pela grande importância que nossos escritores passaram a dar então às memórias de infância, de que o Menino de Engenho, de José Lins do Rego, pode servir de exemplo. Nunca a infância, com todas as suas dimensões e seus seres intemporais, proustianos, foi mais explorada. Como você naturalmente não ignora, um passe de mágica, da sensação gustativa que dá ao escritor um biscoitinho molhado no chá, o qual lhe tira da memória toda a meninice perdida, passada em Illiers. Pois esse processo de repercussão do tempo seria também usado em larga escala pelos autores brasileiros do Modernismo. (SENNA, 1996, p. 136-137).
\end{abstract}

O gosto pelos saraus literários quando criança, suas experiências "sobrenaturais", imaginativas e suas leituras, já prenunciavam a tendência do poeta para o gosto da criação pela memória. Desse modo, a memória e sua representação na figura da musa será um elemento importante e freqüente na poética de Jorge de Lima, e se faz presente em toda poética de Jorge de Lima e significativamente em Invenção de Orfeu, pois é ela que auxiliará o poeta em sua criação.

Em todo Invenção de Orfeu, o poeta é amparado por uma quantidade enorme de musas, que estão presentes no poema em todos os Cantos, retiradas da tradição literária ou mesmo criadas por ele. No primeiro caso, são representadas por Inês de Castro, Lenora, Eurídice, Beatriz, Ofélia, Penélope, Eumetis, entre outras; no segundo, está figurada em Mira-Celi e também outras provenientes de sua infância como Francisca, Lis, Celidônia, etc. Portanto, o Poeta cria auxiliado por inúmeras divindades. 
É interessante notar a impressionante quantidade de musas mortas presente em Invenção de Orfeu. Em geral, são iniciáticas e ligadas ao reino dos mortos: Eurídice, Lenora, Ofélia, Beatriz, Inês, Mira-Celi e Celidônia. Esta característica das musas limianas parece conter o pressuposto básico da "falta" para ato criador, que nos remete ao caráter órfico de Invenção de Orfeu - o poeta canta, como Orfeu, a falta de sua musa, caso contrário a sua "viagem" (o poema/o seu canto) não existiria.

Uma das grandes questões que o mito de Orfeu nos apresenta é o fato dele ter olhado para trás antes de terminar sua "missão". Por que ele teria agido assim? Por achar que estava sendo enganado pelos seres infernais? Por saudades de sua amada? Por não acreditar em sua punição? Por não conter o desejo de ver Eurídice? Por impaciência? Por imprudência? A respeito dessas questões, derivadas desse tema, é interessante notar a posição de Maurice Blanchot e o modo como ele o relaciona ao ato da criação artística.

\begin{abstract}
ao voltar-se para Eurídice, Orfeu arruína a obra, a obra desfaz-se imediatamente, e Eurídice retorna à sombra; a essência da noite, sob o seu olhar, revela-se como não essencial. Assim traiu ela a obra, Eurídice e a noite. Mas não se voltar para Eurídice não seria menor traição, infidelidade à força sem medida e sem prudência do seu movimento, que não quer Eurídice em verdade diurna e em seu acordo cotidiano, que a quer em sua obscuridade noturna, em seu distanciamento, com seu corpo fechado e seu rosto velado, que quer vê-la, não quando ela está visível mas quando está invisível, e não como a intimidade de uma vida familiar para fazêla viver mas ter viva a plenitude de sua morte.

Foi somente isso o que Orfeu foi procurar no inferno. Toda a glória de sua obra, toda a potência de sua arte e o próprio desejo de uma vida feliz sob a bela claridade do dia são sacrificados a essa única preocupação. Olhar na noite o que a noite dissimula, a outra noite, a dissimulação que aparece. (BLANCHOT, 1987, p. 172).
\end{abstract}

Para o crítico, o artista cria somente a partir de uma falta, ${ }^{1}$ se ele está completo a necessidade de criação desaparece. Orfeu só pode continuar a cantar se não tiver consigo a sua musa, caso contrário cala-se. Mas de forma dialética e problemática surge a questão: como se salvar dessa situação se mesmo o artista em criação sofrerá por causa da ausência da amada? Talvez para se livrar desse conflito a única saída seja privilegiar o humano ao criador. Mas essa solução findaria seu canto e, para Orfeu, esta não é uma boa saída, pois representaria o seu próprio fim.

Blanchot continua sua reflexão apresentando o seguinte argumento:

\footnotetext{
${ }^{1}$ A "falta" é um sentimento universal e inerente ao ser humano e especialmente ao artista, assim Valéry o descreve: "Viver é, a todo instante, sentir falta de alguma coisa - modificar-se para atingi-la - e, desse modo, tender a substituir-se no estado de sentir falta de alguma coisa. Vivemos do instável, pelo instável, no instável: essa é a função completa da Sensibilidade, que é a mola diabólica da vida dos seus organizadores. O que há de mais extraordinário para se tentar conceber, e o que pode haver de mais 'poético' para se fazer do que essa força irredutível que é tudo para cada um de nós, que coincide exatamente conosco, que nos movimenta, que nos fala e é falada em nós, que se transforma em prazer, dor, necessidade, desgosto, esperança, força ou fraqueza, dispõe valores, torna-nos anjos ou bestas conforme a hora do dia?" (VALÉRY, 1999, p. 81).
} 
O erro de Orfeu parece estar, então, no desejo que o leva a ver e a possuir Eurídice, ele, cujo único destino é o de cantá-la. Ele só é Orfeu no canto, só pode ter relações com Eurídice no seio do hino, só tem vida e verdade após o poema e por este, e Eurídice não representa outra coisa senão essa dependência mágica que, fora do canto, faz Orfeu uma sombra e não o liberta, vive e soberano, senão no espaço da medida órfica. Sim, isso é verdade: somente o canto de Orfeu tem poder sobre Eurídice, mas também no canto, Eurídice já está perdida e o próprio Orfeu é o Orfeu disperso, o "infinitamente morto" que a força do canto faz dele, desde agora. Ele perde Eurídice e perde-se a si mesmo, mas esse desejo e Eurídice perdida e Orfeu disperso são necessário ao canto, tal como é necessária à obra a prova da ociosidade eterna. Orfeu é culpado de impaciência. Seu erro é ter querido esgotar o infinito, pôr um termo ao interminável, não sustentar sem fim o próprio movimento do seu erro. A impaciência é a falta de quem quer subtrair-se à ausência de tempo, a paciência é o artifício que procura dominar essa ausência de tempo fazendo dela um outro tempo, medido de outro modo. Mas a verdadeira paciência não exclui a impaciência, está na sua intimidade, é a impaciência sofrida e suportada sem fim. A impaciência de Orfeu também é, portanto, um movimento correto: nela começa o que virá a ser a sua própria paixão, sua mais alta paciência, sua morada infinita na morte. (BLANCHOT, 1987, p. 173).

Maurice Blanchot vê no olhar de Orfeu o próprio cerne da inspiração criadora e, em Eurídice, o centro convergente para o qual a arte, o desejo, a morte e a noite parecem dirigir-se. Portanto, a obra nasce da "falta" e da inspiração arrebatadora, e a procura de Orfeu representa o percurso perigoso que o artista empreende em busca da criação.

É também relevante notar que o caráter iniciático e a ligação das musas ao reino dos mortos nos aponta para a ligação do poeta ao Simbolismo a situações biográficas de sua infância, onde viu sua "amiga" (Celidônia) morrer afogada. Outro fato vindo da memória infantil diz respeito à presença de Inês de Castro, episódio da poesia camoniana lida com entusiasmo por seu pai e, seqüencialmente por ele mesmo. Ana Maria Paulino aponta que este tema freqüente na poética limiana também se liga ao topos da "Infanta defunta", o que mostra o diálogo de seus poemas com a composição de Ravel: Pavane pour une infante défunte, inspirada pela lenda da morte da Princesa Polignac. O poeta também se utiliza desse tema no sentido de aproveitar o seu caráter plástico para seus poemas. (ver PAULINO,1995, pp.38-40)

Na estância VII, do Canto Segundo, vemos que Jorge de Lima fará presente em seu poema uma musa do seu imaginário biográfico da infância, Lis. Em suas "Memórias", o poeta nos fala de sua amiga da meninice, protagonista de um acontecimento extraordinário que o marcou profundamente: Lis voando no sarau literário que acontecia em sua casa. ${ }^{2}$ Este "acontecimento" impressionou tanto o poeta

\footnotetext{
${ }^{2}$ Em um dos momentos mágicos de sua infância, o poeta nos conta que numa ocasião em que sua mãe lia para ele e seus amigos, em uma espécie de sarau literário que ocorria em sua casa, em torno de um candeeiro belga (a "esfera armilar"), Os Estranguladores de Bengala, uma história indiana ocorre um fato fabuloso, assim conta o poeta: "Examinávamos uma esfera armilar em que havia no centro uma bola de vidro contendo mariposas que havíamos retirado da treva. E ninguém sabendo o que houve pôs-se Antoninho Gustavo a gritar alucinado: _ Lis está voando. Lis está voando. E olhando Lis e com efeito Lis estava esvoaçando como uma mariposa, em torno da esfera que encerrava a mesa; e corremos em torno da esfera e seguramos Lis pelo vestido de borboleta, e tudo parou, e mãe acudiu, e tudo voltou ao que era. Lis não sabendo o que havia acontecido começou a chorar, e seu pranto desfez em nós a grande alucinação." (LIMA, 1958: 130-131).
} 
que acabou por transformar a amiga da infância em musa. É interessante notar, nesse momento, a relação intrínseca entre a musa do poeta e a memória em seu sentido mítico, como já dissemos, o canto (as Musas) é nascido da Memória (Mnemosyne). É através da memória e de sua musa (Lis) que Jorge de Lima viabiliza seu canto. Esse aspecto é constante no seu poema, onde encontramos um número grande de Musas, como já dissemos, sejam elas criadas pelo poeta ou retiradas da tradição literária. Nesse sentido, o poeta tem na palavra cantada o poder de ultrapassar e superar todos os bloqueios das distâncias espaciais e temporais, um poder que só the é conferido pela Memória (Mnemosyne), através das palavras cantadas (Musas).

É importante notar que o primeiro contato de Jorge de Lima com a poesia provém da infância e é essencialmente lúdico. Nasce dos jogos e brincadeiras infantis, das leituras de contos e fábulas feitas por sua mãe, da própria imaginação do poeta menino ou mesmo dos primeiros contatos com a leitura, como se lê nas suas Memórias. Desse modo, podemos observar claramente que a concepção poética de Jorge de Lima se articula entre o lúdico e sua realidade infantil. É o que se nota não somente em Invenção de Orfeu, como também em praticamente toda a sua poesia.

Ao retirar o poético do mundo infantil e de sua memória, vemos a tentativa do poeta em instaurar um novo mundo, revelado em Invenção de Orfeu por suas imagens carregadas de emoção poética e pela busca de um sentido original para sua poesia.

Tudo é lícito aqui nessa Sumatra.

Lícito desmontar-te, Lys, teus seios

e neles pôr teus olhos renegados,

desacertando a glória que Deus fez;

e depois desconstruir-te, Lys inata,

carne subterfugida e doces veias,

restituindo-se à noite desgarrada

nos baixios submersos do teu leito.

E adorar-te anjo meu reproduzido, biografado dos anjos parricidas, sem sentido de lógicas estrofes,

pois meu grito danado é o mesmo grito

encerrando no ventre dos ouvidos,

repercutindo pelos céus que sofres. (O.C., 1958, p. 680)

Este candeeiro familiar, originalmente à querosene, tem um valor especial na poesia limiana. Acompanhou o poeta desde sua estadia em União dos Palmares, em sua primeira infância, até a mudança para Maceió, cidade onde já havia luz elétrica. 0 candeeiro teve que ser levado a Maceió e adaptado à energia elétrica porque as crianças da família Lima, acostumadas à luz do lampião - além de sua relação afetiva 
com este objeto -, só estudavam em sua presença. ${ }^{3}$ A presença da "esfera armilar" na poesia de Jorge de Lima é constante, já a notamos em: "O mundo do menino impossível" ("O menino poisa a testa/e sonha dentro da noite quieta/da lâmpada apagada/com ele tirou do nada [...]"); no Livro de Sonetos: ("Éramos seis em torno de uma esfera/armilar. Um candeeiro antigo diante/de seus olhos.") e em "Candeeiro familiar" - Poemas dispersos -, em que a imaginação infantil transfigura o objeto em uma série de projeções de imagens.

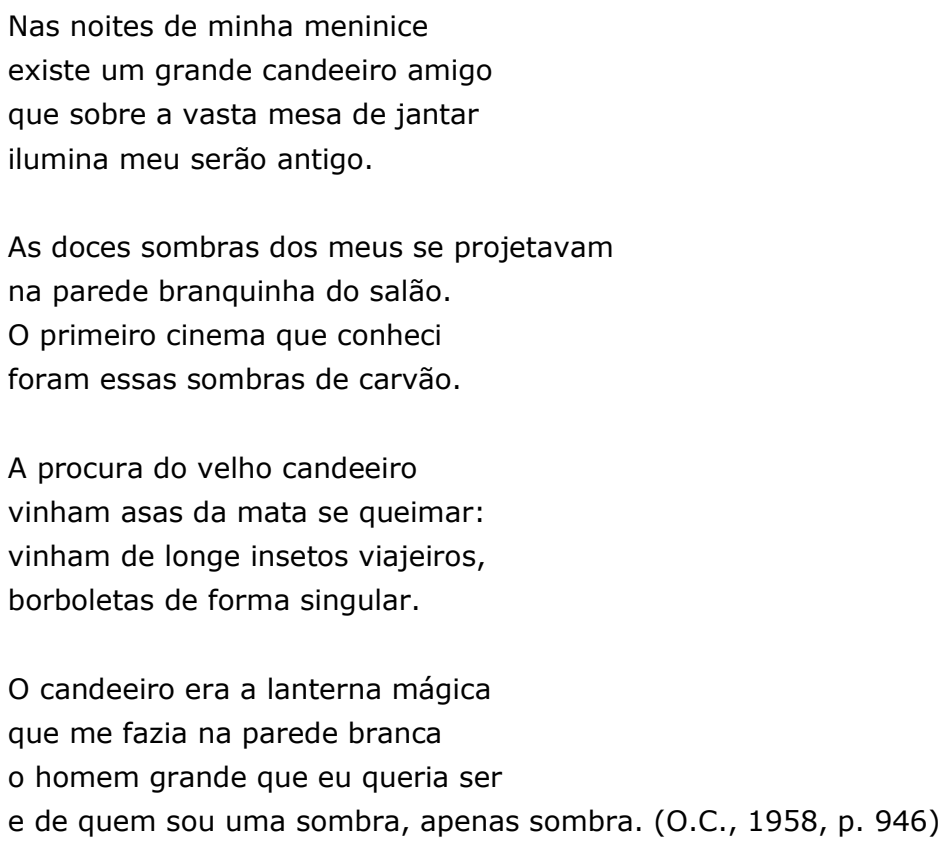

Em várias passagens de Invenção de Orfeu o candeeiro belga está presente: "Lemos contos de Grimm, colamos mariposas/nesse jato de luz em frente às velhas tias" ("I, XXIV"); "grandes lâmpadas, focos de falenas,/as falenas no chão sem asas." ("II, XIV"), "Falenas _ prata e luz, esvoaçar lento/em torno ao candeeiro familiar./Alguém sobre os degraus (hiato no poema,/recordação tenaz, terrível voz!)" ("V, III"); "Nesse ambiente, conhece-se um candeeiro;/éramos quantos rabiscando quadros?" (VIII), novamente no Canto (VIII), "éramos cinco, eu bem me lembro dessa/menina loura que se pôs a alar-se," etc.. Este candeeiro representa, na poesia limiana, a transfiguração do mundo infantil em poesia.

\footnotetext{
3 Assim o poeta nos relata a presença deste candeeiro: "garatujávamos com lápis de cor; começamos as leituras comoventes: Inocência; Graziela [...] Tínhamos livros de lições de coisas com experiências de mágicas familiares". Dessas reuniões, onde igualmente se distraíam com "artes ocultas", além do irmão José Matheos, participavam outros companheiros: Antoninho, Gustavo, João Moreira, Zé Peluzio, Dagoberto e Lys, irmã deste último. "Vinham meninos da vizinhança atraídos pelo que se passava à luz do candeeiro. O círculo iluminado dourava as faces pintadas para As Mil e Uma Noites". (LIMA, 1958:130). Através desta nomeação dos participantes dos saraus literários que aconteciam em sua casa, feita pelo poeta, sabemos que são sete os membros participantes. Assim se esclarece a divergência quanto ao número de pessoas freqüentadoras destes saraus, que hora aparece como sendo seis: em Livro de Sonetos; quatro e cinco no Canto VIII (Biografia) de Invenção de Orfeu
} 
Na estância XV, do Canto Segundo, o poeta também faz um chamamento à musa, que ele denomina como "A excelsa musa" na margem do livro, para habitar um lugar especial em seu poema. Neste soneto, a poesia é tratada como uma musa que recebe oferendas: peixe e mel. Estes alimentos extremamente simbólicos possivelmente representam Cristo e são os mesmos oferecidos apenas aos heróis eleitos. Em Invenção de Orfeu eles são reservados ao herói-poeta para que este possa garantir seus dons.

Através da imagem do espelho a poesia é vista num sentido duplo: em si mesma e em seu reflexo. Dessa forma, o poema parece indicar que a salvação está em nós mesmos, mas projetada em outro espaço, o espaço da transfiguração do eu em outro. Imagem transfigurada no espelho.

\footnotetext{
Vem amiga; dar-te-ei a tua ceia

e a comida que acaso desejares,

e algum poema que ilumine os ares

menos que a luz malsã dessa candeia.
}

Aqui terás o peixe desses mares

e o mais gostoso mel de toda a aldeia.

De onde vens? De que cimos? De que altares?

Que luz angelical te agita a veia?

Como te chamas vida da outra vida, espelho noutro espelho transmudado, lume na minha luz anoitecida?

Serás o dia à noite do outro lado

de meu ser que nas trevas se apagou?

Ou serás qualquer lume que não sou? (O. C.,1958, p. 701)

Na estância XIX, do mesmo Canto, sua seqüência, o poeta canta um lugar bucólico em que ele está intrinsecamente ligado à terra e também à sua infância. A este ambiente se relaciona a musa Inês de Castro, que também habita uma ilha paradisíaca, como vemos na estância XIX do Canto Segundo: "As fontes dulçurosas desta ilha/promanam da rainha viva-morta;" (O.C., 1958, p. 704). Nesse momento, trazendo o elemento sensual a seu poema Jorge de Lima reconta a famosa história de Inês de Castro ${ }^{4}$, que representará uma espécie de guia ou símbolo para um novo

\footnotetext{
4 Sobre a presença da musa de Camões em Invenção de Orfeu Jorge de Lima nos diz o seguinte: "o episódio de Inês de Castro representa um símbolo correspondente à perenidade da própria poesia. Portanto, em vez de uma Inês posta em sossego é uma Inês que se transforma a todo momento, mas conserva a sua integridade e perfeição através do tempo e do espaço. (LIMA, 1958, p. 93). Para Alfredo Bosi, a figura de Inês, que fora cantada por Camões, "é transformada miticamente em mais um dos símbolos femininos da Graça: como Mira-celi, Inês que fulge quando o dia brilha ou se acinzenta quando o ocaso avança, rainha negra, mãe e branca filha, entre arcanjos do céu, andarilha, andar inconsciente que não cansa." Para o crítico, "Estas e outras metáforas procuram significar uma existência que, a rigor, é inesgotável, logo fora ao alcance da apreensão meramente lingüística. Inês, como a Graça, como a Vida, não cessa de irradiar e esse processo ad infinitum acende à estrutura superficial do texto por meio de qualificações múltiplas, contraditórias e simultâneas. [...] O limite da nomeação febril é o desejo vivo de Jorge de Lima: saltar do texto para a fruição do élan vital chamado femininamente Inês.". (BOSI, 1978, pp.155-56.).
} 
mundo recomeçado: "vai ser constelação de um mundo novo,/Esperança maior de eterno povo."

Estavas linda Inês posta em repouso

mas aparentemente bela Inês;

pois de teus olhos lindos já não ouso

fitar o torvelinho que não vês,

o suceder dos rostos cobiçoso

passando sem descanso sob a tez;

que eram tudo memórias fugidias,

máscaras sotopostas que não vias.

Tu, só tu, puro amor e glória crua, não sabes o que à face traduzias.

Estavas, linda Inês, aos olhos nua, transparente no leito em que jazias.

Que a mente costumeira não conclua, nem conclua da sombra que fazias, pois, Inês em repouso é movimento, nada em Inês é inanimado e lento.

As fontes dulçurosas desta ilha promanam da rainha viva-morta; o punhal que feriu é doce tília de que fez a atra brisa santa porta, e em cujos ramos suave porta, e em cujos ramos suave se enrodilha, e segredos de amor ao céu transporta. Não há na vida amor que em vão termine, nem vão esquecimento que o destine. [...]

E para que não finde a eterna lida e tudo para sempre se renove nessa constante musa foragida; entre Andrômedas e Órions alas move.

A sua trajetória é tão renhida, que a multidão celícola comove. Vai ser constelação de um mundo novo, Esperança maior de eterno povo.

Ó paz, ó fim, ó mundo inominado descansa doce névoa mensageira. Teu rosto primogênito gelado, que pólen misterioso te empoeira? Calendário de lumes começado, dormida potestade, luz primeira, eras ontem rainha, hoje és ritual. Que destino de gente supra-real! (O.C., 1958, p. 704) 
O que dissemos sobre a transfiguração a partir do duplo na estância XV parece estar representado neste poema. Inês passa a ser a musa de Jorge de Lima por meio de um diálogo que se estabelece entre o episódio de Inês de Castro (d'Os Lusíadas) com Invenção de Orfeu, que de forma retrabalhada apresenta-se como uma nova heroína. Desse modo, Inês se torna outra a partir das características já possuídas por ela provindas da criação de Camões somado à sua transformação por meio da recriação feita por Jorge de Lima. Nesse momento, Inês não está mais em repouso e sim em movimento. Dessa maneira, é acrescentado um atributo fundamental de Invenção de Orfeu à musa camoniana, o movimento.

O cotejo entre a variante da imagem de Inês de Castro do épico de Camões e do "épico" de Jorge de Lima também mostra, como observa Castello, que não prevalece mais em Invenção de Orfeu a associação, tradicional na poesia, do amor à morte, "mas sim uma visão de amor através da superação pelo sacrifício das contingências humanas, desiguais, na vida terrena. Eliminando-se as restrições do contexto histórico para a projeção atemporalizada da essência lírico-amorosa despida do envolvimento da crueldade, da vingança e também da fatalidade limitadoras em termos de crônica individual." (CASTELLO, 1999, p. 221). É o que ocorre com Mira-Celi (associada ou integrada a Inês de Castro) em um fragmento do Canto Oitavo: ela é ubíqua e sua presença é sentida nos "jardins intemporais", ou seja, em um lugar, poderíamos dizer, utópico. A musa criada pelo poeta o ajuda a captar os momentos de eternidade contra o mal representado aqui pelo tempo - o que pode significar também os momentos poéticos.

E veio para Inês justalinear, a defunta princesa soterrada que ilumina as comunas recalcadas.

Mira-Celi é sentida em ubiqual presença nos jardins intemporais do vasto mar dormido, circundada.

Ela me faz captar esses instantes

de eternidade contra o mal que é o tempo, ela me torna imenso ou pequenino, eu enguia de Deus, ou ossos e ossos. E vendo um campo de esqueletos nus, ela a magia fê-los encarnar-se.

E canso-me à procura das fugazes presenças, e momentos das terríveis ou divinas arquiasas permanentes, para remanescer as durações, e para substituir, gravar um símbolo na casa antiga da árvore perdida. (O. C., Canto VIII, 1958, p. 844) 
O Canto Oitavo, o maior do poema, feito em uma única instância, nos oferece uma grande quantidade de referências ao mudo do sonho. Nota-se que neste Canto o poeta busca cruzar a camada superficial do real e retomar um mundo submerso. Para isso, ele também se compara ao feiticeiro e ao mago ${ }^{4}$, revelando sua missão de procura do sentido oculto das coisas e de edificar outras realidades, transformando a realidade baseada na experiência em realidade poética, através do imaginário e do sonho. Desse modo, com a inserção do sonho e do imaginário na poesia ela acaba se caracterizando como um espaço utópico, onde a renovação do mundo real se dá através do onírico. Isso ocorre também na questão formal do poema, em que o elemento utópico está presente no modo como o poeta reorganiza os significados semânticos das palavras e faz uso da metáfora, deixando que o leitor perceba a linguagem redimensionada do poema e a identifique com uma reordenação das palavras de modo antes não pensado. Isto se dá justamente pelo caráter imaginativo e transformador da linguagem dos sonhos, que proporciona o encontro do poeta com esse "mundo perdido" (e/ou prometido) que é a própria poesia. Nessa perspectiva, a linguagem poética através da imaginação procura reconstruir os elementos formadores desse mundo na tentativa de recuperar o tempo da origem, anterior à queda do homem no paraíso edênico.

Neste Canto, assistimos a formação de um novo mundo ("Forma-se um timbre novo com esses bosques") que se dá por meio de novas musas (da infância do poeta: Isadoras, Isas, Ineses, Lúcias), musas ainda meninas (registro biográfico do autor) e através do pictural ("e nas noites de lua, cabeleiras/de moças debruçadas, dos sobrados"), como demonstram as referências ao ambiente bucólico dos contos infantis e às personagens dessas histórias, como são exemplares "Gúliver" e a Gata Borralheira. A fonte de criação de Jorge de Lima também vem desse universo infantil e são também suas musas biográficas que fornecem a inspiração poética necessária para a construção do poema. E como quer o pensamento mítico, para aparição do poético é necessário que as Musas sejam pronunciadas para que elas se mostrem como força numinosa, consentindo que o canto se desenvolva plenamente.

\footnotetext{
O som-metal alastra-se nos reinos minerais, nas partículas rebeldes desabadas de estrelas, ou saídas de minas que soltaram seus ossuários, seu estanho de vísceras fundidas, reconfluídas num gúliver sonâmbulo.
}

\footnotetext{
${ }^{4}$ Raymond nos explica a distinção entre o poeta e o místico. Para ele: "o poeta é aquele que cria, que faz um objeto cuja matéria é a linguagem, e que essa intenção de fazer é o princípio que orienta e unifica seus poderes. (Mas, o poeta, comprometendo-se por inteiro com outros poderes que não os da inteligência fabricadora transgride inevitavelmente seu objetivo; engendra um ser microcósmico que tende ipso facto a reproduzir analogamente o grande 'mundo', sentido ou pressentido por ele de forma obscura). Desse ponto de vista, discerne-se melhor qual tentação assalta os modernos: a de querer alcançar imediatamente o Absoluto, por uma experiência que quase se confundira com a dos místicos, para encerrá-la em alguma imagem ou símbolo. Assim Baudelaire falava de raptar o paraíso de uma só vez. Mas o 'conhecimento' poético, ou o chamado assim, acompanha a experiência; ela Ihe é consubstancial; e a experiência do que se trata é a do criador" (RAYMOND, 1997: 310).
} 
Forma-se um timbre novo com esses baques de estrelas, com esses uivos de trombetas, com esses sons minerais, com esses despenhos, com esses tombos, um timbre de além sino, ressonando no peito das criaturas ou sobre elas, chorando de antemão.

E aqui estão nossas musas dos sete anos inda meninas, tranças, velocípedes; e nas noites de lua, cabeleiras de moças debruçadas, dos sobrados, descendo como gatas borralheiras por sobre os nossos lábios descuidados.

Ó meninos, ó noites, ó sobrados, ó sonetos vindouros, quatro andares de rimas e azulejos, Isadoras, Isas, Ineses, Lúcias, inda em flor, os dias transformando-me e a vós outras relativas pessoas. Nós aqui.

Nós aqui olhando olhos que nos viram e não nos entenderam tão mudados; eles também os olhos que nos viram jamais nos compreenderam por mostradas as faces transformadas, hoje claras pela luz das estrelas derrubadas. (O.C., 1958, p. 869)

É a memória do passado infantil que devolve o sentido da origem ao poeta, numa seqüência de passagem temporal e mesmo sobrenatural ("depois meus tontos passos noutras vidas,"); do além mundo toda vida pregressa do poeta é passada em revista. E como sugere o primeiro verso como toda a última estrofe do poema, a reconquista da ilha (ou do tempo original) é feita por meio da linguagem: "Em verdade uma volta pelos signos".

Diante disso, torna-se cada vez mais claro, na obra de Jorge de Lima, um desejo expresso de retorno à inocência, à pureza e ao tempo original. Em uma espécie de sonho com a existência primordial, o poeta se afasta do tempo presente devastado pela miséria do mundo adulto, e luta sua "cruzada cristã", resistindo à senilidade e à rigidez na busca do reencontro com a alegria, a beleza, a inocência; enfim, tudo aquilo que a infância representa.

Uma das musas mais significativas da poesia limiana e que marca forte presença em Invenção de Orfeu é Mira-Celi. Musa proveniente de sua poesia anterior, Enunciação e Encontro de Mira-Celi (1943), é caracterizada por sua complexidade interpretativa e à infância do poeta. O próprio Jorge de Lima nos previne sobre a complexidade dessa musa: 
Acho dificuldade de explicar à professora americana a vida de Mira-Celi. A vida, a origem, os jogos, o conhecimento dela, tudo inexplicável. Ainda menino, encontramo-nos durante uma convalescença, depois em outras, em outras depois, em momentos que não posso precisar. [...] Não procuremos exegeses a muitas respostas de Mira-Celi, pois é tida como sonâmbula, e pode, devido a qualquer impertinência, perder-se todo, embora, reapareça inexplicavelmente em todas as solidões ou em quase todos os delírios da febre. Então ide devagar, pé ante pé, porque não estais só, e se conseguires galgar esta escadaria que começa sobre vossa cabeça, alcançareis alguma noções, qualquer certeza, um encontro talvez. Pode toda esta mágica se romper, entretanto, como uma bolha; circundai cauteloso, ficai perplexo para que os últimos tetos não desabem sobre vós. (O.C, 1958, p. 501-02)

\begin{abstract}
Neste livro, a criação poética estará intrinsecamente ligada à inspiração (Mira-Celi é a musa que inspira o poeta) e à busca do sagrado. É o momento em que Jorge de Lima constituirá uma relação profícua com a linguagem mística, com a estética surrealista, estabelecendo uma relação estreita com o mundo noturno, o onírico e o fabuloso, propiciando à imaginação, a magia e a inspiração em sua poesia. Ela será leitmotiv de sua poesia, como podemos ver nos primeiros versos de seu poema número "2": "Tu és, ó Mira-Celi, a repercutida e o laitmotivo/que aparece ao longo de meu poema." (O.C., 1958, p. 507).
\end{abstract}

Este Livro, singular em toda literatura brasileira nos revela muito do que virá adiante na poética de Jorge de Lima. É mesmo uma preparação anunciada para a elaboração de Invenção de Orfeu, que se torna evidente nos versos seguintes: "Os grandes poemas ainda permanecem inéditos." (poema "4") (O.C., 1958, p. 508); "Os grandes poemas começam com a nossa visão desdobrada" (no poema "56") (O.C., 1958, p. 552). Chama a atenção também seu caráter circular, no sentido de que seu primeiro e o último poema começam da mesma maneira como se um fosse continuidade um do outro: "O inesperado ser começou a desenrolar as suas faixas em que/estava a história da criação passada e futura.". Esse aspecto demonstra o desejo, expresso nos dois poemas (Anunciação e encontro de Mira-Celi e Invenção de Orfeu), do rompimento temporal e do encontro do poeta com a eternidade.

Em um momento excepcional (e mítico) de criação de Invenção de Orfeu, a musa Mira-Celi desce entre o ar e o mar e traz de volta a magia para que o poeta possa se expressar. Talvez este seja um dos momentos mais sublimes do "épico" limiano em que as duas musas mais importantes para o poeta se encontram: Inês de Castro (de Camões) e Mira-Celi (criada por Jorge de Lima). É a musa que capacita o poeta a captar "instantes de eternidade" que representam a poesia em si, é aquilo que faz o texto se tornar poético ou mesmo possibilita apreender o instante poético ${ }^{6}$;

${ }^{6}$ No que diz respeito ao instante poético Bachelard tem uma consideração reveladora: "O instante poético é, pois, necessariamente complexo: emociona, prova - convida, consola -, é espantoso e familiar. O instante poético é essencialmente uma relação harmônica entre dois contrários. No instante apaixonado do poeta existe sempre um pouco de razão; na recusa racional permanece sempre um pouco de paixão. As antíteses sucessivas já agradam ao poeta. Mas, para o arroubo, para o êxtase, é preciso que as antíteses se contraiam em ambivalência. Surge então o instante poético... No mínimo, o instante poético é a consciência de uma 
sentimento poético se contrapõe à passagem do tempo inexorável e destruidor de tudo. Neste momento, a poesia, recupera o passado como se conseguisse materializar e/ou armazenar o tempo perdido em seus versos. Nesse sentido, a passagem do tempo para o poeta é vista de maneira negativa, pois é por causa desse movimento temporal que tudo se destrói e se acaba. Assim, os bons momentos do passado, principalmente os relacionados à infância, tanto ao passado infantil do poeta quanto ao referente à infância da humanidade - que de acordo com a ideologia cristã representa o tempo anterior à Queda - são buscados na tentativa de se alcançar a eternidade, materializando-a por meio de pequenos instantes poéticos.

Há também nesse fragmento o redimensionamento da figura do poeta que transita entre o "imenso" e o "pequeno", caracterizando sua mutabilidade constante e que também pode representar a mistura estilística do poema. Isso quer dizer que, em Invenção de Orfeu, o poeta reafirma a não apenas primazia do estilo elevado das grandes epopéias clássicas em seu poema, acrescendo na construção deste o humilde e o pequeno, como apontam suas incursões pelos temas sociais do negro, do nordestino e do índio, presentes no poema.

Invenção de Orfeu também associar-se-á à poesia guiada pelo divino ("eu enguia de Deus"). É por meio da magia que se dá o encantamento do mundo caído, como nos revela os versos: "E vendo um campo de esqueletos nus,/ela a magia fê-los encantar-se". A última estrofe do poema abaixo revela a luta do poeta, com o auxilio da musa e do divino, na busca do tempo dos primórdios perdido, pela queda do homem no Jardim do Éden.

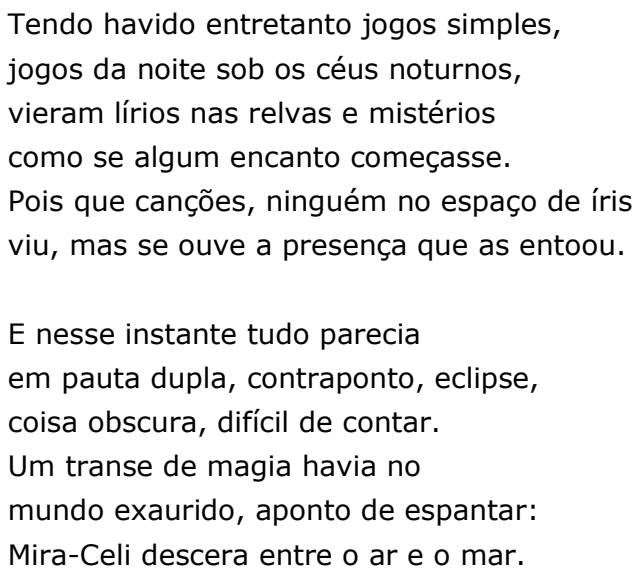

ambivalência. Porém é mais: é uma ambivalência excitada, ativa, dinâmica. O instante poético obriga o ser a valorizar ou a desvalorizar. No instante poético o ser sobe ou desce, sem aceitar o tempo do mundo, que reduziria a ambivalência à antítese, o simultâneo ao sucessivo. Podese verificar facilmente essa relação de antítese e de ambivalência quando se deseja comungar com o poeta que, evidentemente, vive num único instante os dois termos de suas antíteses. $O$ segundo termo não é requisitado pelo primeiro. Os dois termos nascem juntos. Os verdadeiros instantes poéticos de um poema são então encontrados em todos os pontos nos quais o coração humano pode inverter as antíteses. Mas intuitivamente, a ambivalência bem atada revela-se por seu caráter temporal: em lugar do tempo másculo e valente que se arroja e chora, eis o instante andrógino. O mistério poético é uma androginia" (BACHELARD,1991, pp.184-185). 
Nós vimo-la chegar intransitiva, era a musa (seus gestos denunciavam-na), pois estava tardada sem segredos, a face fixa, a fronte pura de água. e o lírio circundante tão brilhado que ela aparecia antes e no fim.

Inconsútil rosácea aquela musa, nesse arco-íris de tarde sublunar, cisne augural ou águia albina, ou agnus. Ela com o lírio albino e o cisne em si, e canto suave entre nereida e anêmona, e o som do verso em Mira-Celi vindo.

E veio para Inês justalinear, a defunta princesa soterrada que ilumina as comunas recalcadas. Mira-Celi é sentida em ubiqual presença nos jardins intemporais do vasto mar dormindo, circundada.

Ela me fez captar esses instantes de eternidade contra o mal que é o tempo, ela me torna imenso ou pequenino, eu enguia de Deus, eu ossos e ossos. E vendo um campo de esqueletos nus, ela a magia fê-los encantar-se

E canso-me à procura das fugazes presenças, e momentos das terríveis ou divinas arquiasas permanentes, para remanescer as durações, e para substituir, gravar um símbolo na casa antiga da árvore perdida. (O.C., Canto VIII, p. 843, 1958)

Mira-Celi também é a fonte que traz paz ao poeta e ao mundo. Sua fala é a mesma do poema (Invenção de Orfeu), pois diz coisas "inatas" e sem "razão". As mãos que escrevem o poema são transfiguradas pela inspiração dada pela musa; sem ela não há paz nem poesia. O poeta absorve a sensibilidade da musa (suas mãos estão enlaçadas e são transfiguradas em uma só, unindo as duas entidades em uma só pessoa), é "presciente" e "visionário". Ele luta contra o tempo humano, que pode representar, por um lado, o momento vivido pelo poeta (considerado ruim) e, por outro, aquele buscado pelo poeta, mítico e eterno, semelhante ao momento anterior à Queda. Este aspecto reafirma o desejo do reencontro com o paraíso perdido mencionado nos versos anteriores, através da marcação intensa da negatividade (uso da exclamação), representada pela passagem do tempo no último verso: "Ó triste condição do humano tempo!". 
O poeta pretende dar vivacidade ao mundo, oferecendo elementos novos às coisas já existentes: perfume às pedras, odores às coisas desprovidas de cheiro e olhar às coisas pequenas, comumente não vistas. Desse modo, ele constrói, em seu poema, um novo mundo redimensionado, mais vivo e prazeroso, onde os sentidos são mais aguçados. Este mundo redimensionado pretendido pelo poeta se revela mesmo na linguagem do próprio poema, como demonstram a sinestesia "verdes sons", a metáfora insólita "pedras esperando", distinguindo-se do real e mimético. É um mundo configurado de uma forma diferente e por isso mesmo, por sua novidade, pode estar fora da compreensão imediata: "... de desenhos/que a luz não produziu na compreensão.". Soma-se a isso todo o ambiente não usual, que novamente é ditado por uma linguagem carregada de simbolismo mítico e que se expressa por elementos ligados ao mundo fantástico e pela junção de termos estranhos associados uns aos outros: "fantasmas", "[...] falas de fora de/nossas bocas falando para nós.", "voz altas sempre em lábios mudos.", "interminável estribilho surdo.", etc.

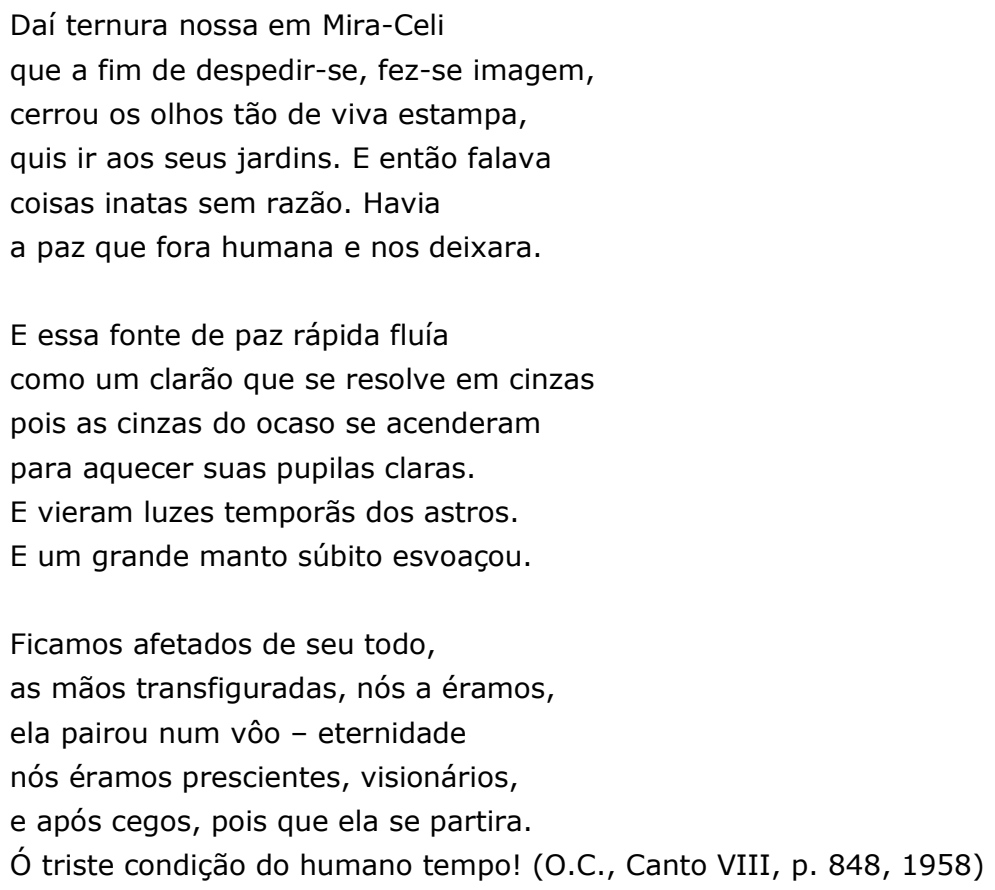

Neste momento, como em vários outros, o poeta aponta que apenas a utilização da razão não é suficiente para criação de seu poema. Para sua completa realização, terá que se somar à razão a memória, o imaginário e a inspiração divina, numa espécie de memória sensitiva em que os vários sentidos (o olfato, a visão, a audição e o tato) auxiliam na re-vivificação dessa memória. A necessidade da criação é grande e a síntese de sua escritura nos é revelada pelo próprio poeta a partir dos elementos elencados no poema: "Memória, raciocínio, descalabro, /liberdade do obsceno e do divino,". Além desses aspectos, outros são vistos: o estado febril (parece até mesmo que o poeta está doente e prestes a perecer) o pedido de ajuda a Deus e seu oferecimento a ele. 
No Canto Nono - também composto por uma estância, significativamente denominado "Permanência de Inês", o que mostra a importância dessa musa para poesia limiana -, há a constatação do poema como múltiplo, mas mesmo com essa caracterização verifica-se a perenidade da infância a partir da presença da musa camoniana Inês de Castro, situada tanto na infância do poeta como a fase final de sua poesia. Como referência biográfica bastante evidente, Inês se mostra, talvez, a musa mais relevante para o poeta, mais importante até do que Mira-Celi, criada por ele mesmo. É fundamental apontar, no entanto, que Mira-Celi surge daquela, ou seja, Inês está dentro de Mira-Celi. Em um quase depoimento, o poeta nos diz que um de seus primeiros momentos de alumbramento poético ocorreu em sua infância, exatamente na leitura do episódio de Inês de Castro feita pelo seu pai - e depois feita por ele mesmo -, fundindo realidade (a presença paterna) e literatura (o texto poético de Camões e sua leitura). Junta-se a isso o alumbramento do poeta menino, experimentando as primeiras sensações causadas pela visão da nudez feminina. Neste fragmento é possível observamos a tentativa do poeta de eternizar este momento de intensa emoção poética. Num poema revelador, ele expõe seu modo de composição do poema: sua temática, a relação de rompimento com o tempo cronológico e a presença do elemento social em sua poesia.

Inês que fulge quando o dia brilha ou se acinzenta quando o ocaso avança, rainha negra, mãe e branca filha, entre arcanjos do céu etérea dança, e nos dias dos mundos andarilha, andar incandescente que não cansa, poema aparentemente muitos poemas, mas infância perene, tema em temas.

Ela fechada virgem, via-a em rio; eu era os meus sete anos, vendo-a vejo a própria poesia que surgiu intemporal, poesia que me vê, verá, me viu, ó mar sempre passado em que velejo eu próprio outro marujo e outro oceano em redor do marujo transmontano.

Meu pai te lia, ó página de insânia! E eu escutava, como se findasses. Findasses? Se tu eras a espontânea, a musa aparecia de cem faces, a além de mim e além da Lusitânia, como se além da página acenasses aos que postos em teus desassossegos, cegam seus olhos por teus olhos cegos.

Ó vidente através, ó Inês mirante, em nós mortes sofridas para versos, para que nesta vida o mundo cante 
e o cego e o surdo e os homens controversos apreendam todos teu geral instante, teus pequenos e grandes universos, teu aparecimento em Mira-Celi, para que tua face se revele. (O. C. Canto IX, 1958, p. 871)

No Canto Décimo, estância XIX, após o viajante passar pela Ásia e África, rumo possível ao Brasil - ele vê o reverso das coisas ruins, "ainda existia um mundo esperando caravelas", um mundo caracteristicamente paradisíaco por meio de seus elementos constituintes, uma terra gerada pela musa de Dante, Beatriz. Uma terra de poesia (o que também demonstra que seu projeto poético está estreitamente relacionado à forma de seu poema), soprada por Beatriz, onde rios de verbos nascem, signos nunca ouvidos (é o verbo novo, a poesia nova) e memoráveis frutos.

Afinal afastando-nos da costa

para danar as calmarias, vimos

o reverso das coisas e dos seres

com a nudez dos primeiros achamentos;

pois além dos infernos existia

inda um mundo esperando caravelas;

entre a carne aderida e os ossos frios,

sobre os golfos de Dante e os purgatórios

havia a face achada de Beatriz;

_ a alegria, chamemos-lhe com o nome

de uma outra realidade fecundada,

continente com outras geografias

de formas várias, iam esplendores, subiam lácteas mãos, floriam luzes, tempo fluido cobria alados olhos, outros sangues pulsavam seres, óperas, verbos sem leis ardiam sóis ocelos, serviços de ofuscar benignamente, ofícios de cadências prelunares, constâncias renovadas, formosuras, visíveis sons, mistérios devassados, ordenação do estável e grandezas.

Estilhas de linguagem acendidas, insônias repousantes, lanhos doces, verdades sem pensar, pronúncias livres, a frase além dos lábios, jogos lépidos, no cerne a louquidão sempre almejada, os leves manuais discricionários, os cortejos passando novamente, os nomes de outra vez dado às coisas, as coisas renascidas e os batismos, as mãos de Beatriz têm novos números e a fronte nívea é logo nominada. (O.C., 1958, p. 909) 
Desse modo, uma das constantes no poema será a presença do impulso poético que não está submetido antecipadamente a nenhuma regra que o aprisione ou mesmo que não permita que ele ocorra: "verbos sem leis ardiam sóis ocelos,/serviços de ofuscar benignamente/ofícios de cadências prelunares/constâncias renovadas, formosuras,/visíveis sons, mistérios devassados,/ordenação do estável e grandezas.".

É interessante notar o percurso trilhado pelo poeta em Invenção de Orfeu: em primeiro lugar, ele recebe ajuda das musas para realizar seu poema e posteriormente recebe a ajuda divina (juntamente com a de outros poetas: Camões, Ovídio, Dante, Rimbaud, Lautréamont, etc.) para o mesmo fim. De acordo com Curtius, a literatura ocidental após privilegiar o canto, e as musas passa seqüencialmente a invocar os césares para depois chegar à invocação de Deus e, finalmente, à invocação do próprio espírito do poeta. No que se refere à invocação divina a poesia propriamente dita passa a associar-se a poesia cristã, como parece ser o caso de Jorge de Lima que dialoga com esta tradição. Desse modo, Curtius nos diz que: "além de invocar as Musas, a poesia antiga também cultivava a invocação de Zeus, o que permitiu à poesia cristã estabelecer correlações: o paraíso é equiparado ao Olimpo e Deus a Júpiter." (CURTIUS, 1996, p. 297). Somado a isso, o declínio do paganismo revela a razão da rejeição, pela poesia cristã, do culto às musas. Desse modo, os poetas passam a pedir ajuda ao Espírito Santo ou propriamente a Cristo identificado a Orfeu. Assim declara o crítico, a partir das considerações de Paulino de Nola: "Em lugar de Apolo e das Musas, deveria ser Cristo o estimulador e entoador da poesia (XV, 30). Os poetas pagãos proferiram mentiras, o que não assenta bem num servo de Cristo ( $X X, 32$ e 55). Além do protesto contra as Musas pagãs, Paulino desenvolve também uma teoria cristológica da inspiração e uma concepção de Cristo como músico universal que lembra a especulação alexandrina sobre Cristo identificado com Orfeu." (CURTIUS,1996, p. 299). É importante notar estas nuanças na história da poesia, mas como sabemos Jorge de Lima nunca se incomodou, como outros poetas modernistas, em se relacionar com a tradição literária de modo a tirar proveito dela. É por esse motivo que vemos presente em Invenção de Orfeu, poema muitas vezes paradoxal, elementos que aparentemente se opõem. Assim, Jorge de Lima se utiliza das musas ( 0 mundo pagão) - reabilitando-as, como fizeram os humanistas - e do divino (o mundo religioso cristão, muitas vezes associado à figura de Orfeu). Desse modo, ao trazer de volta os mitos ao nosso tempo, o poeta redimensiona-os oferecendo ao leitor moderno um espaço para reflexão a respeito do fazer poético e da própria criação artística.

\section{Referências}

BACHELARD, Gaston. O direito de sonhar. Rio de Janeiro: Bertrand Brasil S. A., 1991.

BLANCHOT, Maurice. O espaço literário. Rio de Janeiro: Rocco, 1987.

BOSI, Alfredo. Camões e Jorge de Lima. Revista Camoniana. 2a série, volume 1. 1978.

BOSI, Alfredo. O Ser e o Tempo na Poesia. São Paulo Cultrix, 1977. 
CASTELO, José Aderaldo. Memória, poesia e ficção em Jorge de Lima. In: A Literatura Brasileira: origens e unidade (1500-1960). São Paulo: EDUSP, 1999.

CAVALCANTI, Luciano M.D. Invenção de Orfeu: a "utopia" poética na lírica de Jorge de Lima. (Tese de Doutorado) Campinas: IEL/UNICAMP, 2007.

CURTIUS, Ernest Robert. Literatura Européia e Idade Média Latina. São Paulo: HUCITEC/EDUSP, 1996.

ELIADE, Mircea. Mito e realidade. São Paulo: Ed. Perspectiva, 1998.

LE GOFF, Jacques. Memória. In: História e memória. Campinas: Ed. UNICAMP, 2003.

LIMA Jorge de. Obra Completa (org. Afrânio Coutinho). Rio de Janeiro: Aguilar, 1958.

PAULINO, Ana Maria. Jorge de Lima - Artistas Brasileiros (Poesia e Pintura). São Paulo: EDUSP, 1995.

RAYMOND, Marcel. De Baudelaire aos surrealismo. São Paulo: EDUSP, 1997.

SENNA, Homero. O mistério poético. In: República das letras: entrevistas com vinte grandes escritores brasileiros. Rio de Janeiro: Civilização Brasileira, 1996.

VALÉRY, Paul. Variedades. (Org. e Int.: João Alexandre Barbosa - Trad. Maiza Martins de Siqueira - Posfácio. Aguinaldo Gonçalves) São Paulo: Iluminuras, 1999.

VERNANT, J. P. Aspectos míticos da memória e do tempo. In: Mito e pensamento entre os gregos: estudos de psicologia histórica. Rio de Janeiro: Paz e Terra, 1990.

\section{Title}

Jorge de Lima's Muses in Invenção de Orfeu

\section{Abstract}

This text aims at examining the presence of the figure of the Muse in Invenção de Orfeu by Jorge de Lima. For that, we will make a small introduction on the origin and meaning of the Muse, for, then after, to analyze as Jorge de Lima if it used of this mythical tradition of the poetical creation in the elaboration of its poem.

\section{Keywords}

Myth. Muse. Memory. Invenção de Orfeu. Jorge de Lima.

Recebido em 17.04.2011. Aprovado em 11.07.2011. 